\title{
STRATEGI PENGEMBANGAN KAWASAN MINAPOLITAN DI KECAMATAN PAMBOANG KABUPATEN MAJENE DALAM KONSEP PENGEMBANGAN WILAYAH
}

\author{
Fatmawaty $\mathbf{D}^{1}$, Ikawati ${ }^{2}$, Erwin Amri $^{3}$ \\ ${ }^{1,2}$ Prodi Agribisnis, Fakultas Pertanian dan Kehutanan Universitas Sulawesi Barat \\ ${ }^{3}$ PPW Pasca Sarjana Universitas Hasanuddin \\ ${ }^{1,2}$ Email : fatmawaty.damrah@unsulbar.ac.id 'ikawati@unsulbar.ac.id \\ Diterima (received): 17Februari $2018 \quad$ Disetujui (accepted): 19 April 2018
}

\begin{abstract}
ABSTRAK
Kawasan minapolitan merupakan kawasan yang dibangun atau dikembangkan dengan konsep yang difokuskan kepada kemajuan sektor perikanan dengan mengedepankan prinsip efisiensi, kualitas, percepatan dan berkesinambungan. Konsep dasar pengembangan Kawasan Minapolitan adalah upaya menciptakan pembangunan interregional berimbang, khususnya dengan meningkatkan keterkaitan pembangunan kota-desa (rural-urban linkage) yaitu pengembangan kawasan pedesaan yang terintegrasi di dalam sistem perkotaan secara fungsional dan spasial. Penelitian ini dilakukan di Kecamatan Pamboang, Kabupaten Majene dengan luas wilayah 7.019 hektar. Tahapan analisis yang dilakukan pada penelitian ini yaitu: (1) Analisis pengembangan wilayah berbasis perikanan; (2) Analisis pengembangan komoditas unggulan; dan (3) Penentuan strategi pengembangan wilayah untuk kawasan minapolitan. Berkembangnya kawasan minapolitan sangat ditentukan oleh pengembangan komoditas unggulan di setiap kawasan Minapolitan. Penetapan komoditas unggulan sangat bermanfaat dalam menentukan prioritas pengembangan disuatu wilayah yang harus disusun secara terstruktur dalam sistem perencanaan yang jelas. Agar pengembangan ini tepat sasaran maka perlu arahan strategi dalam pengembangan komoditas unggulan diantaranya meningkatkan koordinasi lintas sektor, peningkatan sosialisasi dan promosi, peningkatan SDM dan kelembagaan, Teknologi Tepat Guna serta terbangunnya fasilitas fisik minapolitan.
\end{abstract}

Kata Kunci : minapolitan, wilayah, value chain

\section{A. PENDAHULUAN}

Pelaksanaan pembangunan nasional yang dijalankan di Indonesia secara lebih sederhana dibedakan dalam bentuk pembangunan sektoral dan pembangunan regional. Dalam konteks pembangunan regional, pemerintah telah menggariskan suatu kebijakan yang menghendaki agar pembangunan tidak dilaksanakan secara terpusat melainkan diharapkan melalui pembangunan daerah sehingga dapat membangkitkan prakarsa serta partisipasi masyarakat secara luas untuk turut serta dalam mendukung dan menyukseskan pelaksanaan pembangunan sesuai dengan kondisi wilayahnya (Susanto, 2014).

Berbagai kebijakan, program serta kegiatan pembangunan di sektor kelautan dan perikanan telah dilaksanakan dan dirasakan manfaatnya. Namun, sejalan dengan perubahan yang begitu cepat di segala bidang, baik secara internasional maupun nasional, maka kebijakan, program dan kegiatan pembangunan sektor 
Fatmawaty D, Ikawati dan Erwin Amri, Strategi Pengembangan Kawasan Minapolitan di Kecamatan Pamboang Kabupaten Majene dalam Konsep Pengembangan Wilayah

kelautan dan perikanan memerlukan penyesuaian atau perubahan agar dapat memenuhi kebutuhan ekonomi yang lebih fokus pada peningkatan kesejahteraan rakyat.

Sektor perikanan merupakan sektor yang penting bagi masyarakat Indonesia dan dapat dijadikan sebagai penggerak utama (prime mover) perekonomian nasional. Hal tersebut didasarkan bahwa sektor perikanan memiliki potensi yang sangat besar dilihat dari perairan Indonesia yang memiliki luas 5,8 juta $\mathrm{km}^{2}$. Selain itu, Indonesia memiliki garis pantai $95.181 \mathrm{~km}$, yang sebagian besar menjadi basis kegiatan ekonomi perikanan (Departemen Kelautan dan Perikanan, 2009).

Kesenjangan antara kawasan perkotaan dan pedesaan menghasilkan kemiskinan dipedesaan, dan proses urbanisasi yang tidak terkendali semakin mendesak produktivitas lahan. Berdasarkan fakta tersebut maka telah ditegaskan dalam Program Nasional bahwa sasaran pokok pembangunan diantaranya adalah menurunnya jumlah penduduk miskin serta terciptanya lapangan kerja yang mampu mengurangi pengangguran terbuka dengan didukung oleh stabilitas ekonomi yang tetap terjaga; dan sasaran kedua adalah berkurangnya kesenjangan antar wilayah. Salah satu konsep pengembangan pedesaan adalah pembangunan dengan konsep kawasan seperti Kawasan Minapolitan, yang diharapkan dengan adanya kawasan tersebut maka akan dapat meningkatkan perekonomian masyarakat disekitar kawasan.

Penentuan komoditas ikan unggulan di suatu daerah merupakan langkah awal menuju pembangunan dan pengelolaan perikanan tangkap yang berpijak pada konsep efisiensi untuk meraih keunggulan komparatif dan kompetitif dalam menghadapi globalisasi perdagangan. Langkah menuju efisiensi dapat ditempuh dengan menentukan komoditas ikan yang mempunyai keunggulan komparatif, baik ditinjau dari sisi penawaran maupun permintaan, serta keunggulan daya saing tinggi. Dari sisi penawaran, komoditas ikan unggulan dicirikan oleh superioritas dalam pertumbuhan pada kondisi biofisik, teknologi, dan sosial ekonomi nelayan yang dapat dijadikan andalan untuk meningkatkan pendapatan (Naya et al. 2017). Berdasarkan uraian diatas maka perlu dilakukan suatu penelitian mengenai strategi pengembangan kawasan minapolitan sebagai pusat pertumbuhan ekonomi di daerah khususnya Kecamatan Pamboang di Kabupaten Majene sebagai salah satu upaya untuk meningkatkan perekonomian masyarakat.

\section{B. METODE PENELITIAN}

Penelitian ini dilakukan di Kecamatan Pamboang Kabupaten Majene dengan luas wilayah 7.019 ha. Tahapan analisis yang dilakukan pada penelitian ini yaitu :

\section{Analisis Pengembangan Wilayah Berbasis Perikanan}

Tahapan ini, analisis yang dilakukan berupa identifikasi potensi dan masalah kawasan minapolitan. Identifikasi dilakukan terhadap isu-isu lokal maupun isu nasional yang ada. Hasil identifikasi isu dan masalah tersebut kemudian dijadikan sebagai acuan dalam melakukan analisis potensi untuk pengembangan kawasan minapolitan menggunakan analisis SWOT. 
Fatmawaty D, Ikawati dan Erwin Amri, Strategi Pengembangan Kawasan Minapolitan di Kecamatan Pamboang Kabupaten Majene dalam Konsep Pengembangan Wilayah

\section{Analisis Pengembangan Komoditas Unggulan}

Tahapan kedua analisis yang dilakukan adalah identifikasi potensi yang ada di Kecamatan Pamboang. Potensi tersebut berupa jenis ikan yang termasuk kedalam komoditas unggulan, baik itu perikanan darat maupun perikanan tangkap. Analisis tahapan ini dilakukan dengan menggunakan metode LQ dan supply chain (analisis rantai pasokan).

\section{Penentuan Strategi Pengembangan Wilayah}

Pengembangan wilayah dilakukan dengan mendeskripsikan hasil dari analisis yang telah dilakukan pada dua tahapan sebelumnya.

\section{HASIL DAN PEMBAHASAN}

\section{Pengembangan Berbasis Perikanan}

Salah satu faktor kunci keberhasilan pembangunan antara lain terletak pada kemampuan pengambil dan penyusun kebijakan dalam memahami isu dan permasalahan yang berkembang di masyarakat. Oleh karenanya identifikasi isu dan permasalahan terkait dengan pengembangan minapolitan menjadi suatu yang sangat strategis. Hasil identifikasi terhadap isu dan masalah akan mencerminkan kekuatan dan kelemahan dalam pengembangan kawasan perikanan budidaya. Disisi lain, isu dan permasalahan tersebut juga akan mencerminkan peluang dan ancaman yang datangnya dari luar. Oleh karena itu, disusun suatu matrik untuk menjelaskan secara rinci tentang upaya-upaya yang perlu dilakukan untuk mengatasi berbagai kelemahan internal dan menanggulangi ancaman yang mungkin terjadi dari luar. Atas dasar hal tersebut, selanjutnya dapat dilakukan upaya-upaya untuk mengatasi permasalahan tersebut dengan menggunakan kekuatan dan memanfaatkan peluang yang ada.

Tabel 1. Strategi dan arahan kebijakan pengembangan kawasan minapolitan

\begin{tabular}{|c|c|c|}
\hline No & Strategi & Arah Kebijakan \\
\hline 1 & Strategi SO & \\
\hline & $\begin{array}{l}\text { 1. Peningkatan sosialisasi dan } \\
\text { promosi }\end{array}$ & $\begin{array}{l}\text { a. Menyusun program promosi pengembangan } \\
\text { kawasan minapolitan dan perikanan }\end{array}$ \\
\hline & 2. Peningkatan suasana kondusif & $\begin{array}{l}\text { b. menyusun program pelayanan yang baik dan } \\
\text { prima }\end{array}$ \\
\hline & 3. Terealisasinya RTRW & $\begin{array}{l}\text { c. Menyusun program pendidikan formal yang } \\
\text { mendukung pengembangan kawasan } \\
\text { Minapolitan }\end{array}$ \\
\hline & $\begin{array}{l}\text { 4. Meningkatkan profesionalisme } \\
\text { pengelola dan regulasi perikanan }\end{array}$ & $\begin{array}{l}\text { d. Menyusun konsep pembangunan yang } \\
\text { terintegrasi }\end{array}$ \\
\hline
\end{tabular}

2 Strategi WO

1. Perkuat lembaga pendidikan perikanan budidaya

a. Menyempurnakan pendidikan formal dan nonformal perikanan untuk mendukung pengembangan kawasan Minapolitan

2. Terbangunya fasilitas fisik Minapolitan

b. Melaksanakan pembangunan sarana dan prasarana Minapolitan dan meningkatkan koordinasi lintas sektor

3. Perkuat SDM Penyuluh

c. Menambah dan meningkatkan mutu SDM perikanan, baik aparat terkait maupun pengelolanya untuk mendukung kawasan 
Fatmawaty D, Ikawati dan Erwin Amri, Strategi Pengembangan Kawasan Minapolitan di Kecamatan Pamboang Kabupaten Majene dalam Konsep Pengembangan Wilayah

\begin{tabular}{lll} 
Strategi ST & \\
$\begin{array}{l}\text { 1. Meningkatnya koordinasi } \\
\text { sinkronisasi program/kegiatan }\end{array}$ & $\begin{array}{l}\text { a. Membentuk tim lintas sektor untuk menyusun } \\
\text { program/kegiatan jangka pendek dan menengah } \\
\text { sesuai master plan }\end{array}$ \\
$\begin{array}{l}\text { 2. Meningkatnya dana } \\
\text { pembangunan sektor perikanan }\end{array}$ & $\begin{array}{l}\text { b. Meningkatkan dana pembangunan sektor } \\
\text { perikanan untuk pengembangan Minapolitan } \\
\text { dari berbagai sumber dana lain }\end{array}$ \\
$\begin{array}{ll}\text { 3. Pelestarian kondisi lingkungan, } \\
\text { khususnya kawasan serapan air }\end{array}$ & $\begin{array}{l}\text { c. Merancang dan meningkatkan pelestarian } \\
\text { lingkungan dan program kebersihan lingkungan }\end{array}$ \\
\hline $\begin{array}{l}\text { Strategi WT } \\
\text { 1. Optimalnya pelaksanaan }\end{array}$ & $\begin{array}{l}\text { a. Membuat rencana definitif dan dukungan } \\
\text { pemanfaatan lahan berdasarkan }\end{array}$ & $\begin{array}{l}\text { anggaran untuk pelaksanaan pemanfaatan lahan } \\
\text { berdasarkan RTRW yang telah ditetapkan }\end{array}$ \\
RTRW & b. Mengoptimalkan pengendalian dampak negatif \\
2. Pengendalian dampak negatif & atas pelaksanaan pengembangan kawasan \\
kawasan Minapoltian & Minapolitan di lingkungan masyarakat sekitar \\
& c. Melakukan/meningkatkan sinkronisasi \\
3. Terumuskannya sinkronisasi & kebijakan pembiayaan atas pengembangan \\
kebijakan pembangunan antar & kawasan Minapolitan baik secara sektoral \\
sektor/SKPD dan antara daerah, & maupun antar wilayah dan nasional
\end{tabular}
Sumber: hasil analisis tahun 2016

Dalam tatanan regional berdasarkan Rencana Tata Ruang Wilayah (RTRW) Kabupaten Majene, Kawasan Minapolitan termasuk dalam klasifikasi Pusat Pelayanan Lingkungan (PPL), dengan kemampuan jangkauan pelayanan skala kawasan. Dengan demikian maka Kawasan Minapolitan Pamboang secara fungsional memiliki peran penting dalam memicu pertumbuhan Kabupaten Majene. Sekalipun tidak berada pada posisi sebagai ibukota kabupaten, tetapi secara fungsional, Kabupaten Pamboang merupakan pusat pelayanan dan pengembangan kawasan peisir dan sekitarnya. Dalam mencermati pentingnya fungsi Kawasan Minapolitan ini, maka untuk penataan ruangnya dalam tinjauan regional, direkomendasikan hal-hal konsepsional sebagai berikut:

1. Pengembangan infrastruktur perhubungan inter-regional jalan Trans Sulawesi-Majene-Mamuju dalam menjaga fungsinya sebagai pusat pelayanan kawasan;

2. Pengembangan sarana dan prasarana kawasan minapolitan meliputi Sarana pendukung minapolitan (pendidikan, perkantoran pemerintah, pasar) dan infrastruktur kawasan (jalan, jembatan, listrik, persampahan dan air bersih).

3. Pengembangan ruang-ruang jasa, perdagangan, dan jasa, serta pelayanan aktifitas kota sebagai elemen pemicu utama pertumbuhan perekonomian di Kabupaten Majene dan kawasan minapolitan Pamboang khususnya;

4. Pengembangan pusat-pusat kegiatan baru, untuk mendukung pengembangan wilayah baru terutama Pusat Kegiatan Lokal Promosi (PKLp);

5. Pengembangan Pamboang sebagai kawasan strategis minapolitan.

Wilayah sentra produksi utama perikanan tangkap adalah di seluruh wilayah pesisir Kecamatan Pamboang, desa-desa sentra produksi perikanan darat dengan komuditi bandeng, udang windu dan ikan lainnya yang berada di tiga kecamatan wilayah Kecamatan Pamboang khususnya di Kelurahan Lalampanua. Sedangkan 
Fatmawaty D, Ikawati dan Erwin Amri, Strategi Pengembangan Kawasan Minapolitan di Kecamatan Pamboang Kabupaten Majene dalam Konsep Pengembangan Wilayah

wilayah sentra produksi pendukung berada di Desa Bababulo, Bababulo Utara, dan Desa Tinambung. Wilayah ini dijadikan wilayah pendukung karena telah ada rintisan kawasan minapolitan. Analisa kebutuhan benih ikan di Kecamatan Pamboang masih sangat terbuka luas oleh karena itu pengembangan pembenihan dan pembesaran ikan Bandeng, udang dan ikan tawar lainnya akan menjadi usaha selaian perikanan tangkap bagi masyarakat di Kecamatan Pambong dan diharpakan pada tahuntahun yang akan dating ketiga kecamatan tersebut akan menjadi kawasan minapolitan berikutnya di Kabupaten Majene.

\section{Pengembangan Komoditas Unggulan}

Analisis pemusatan ini dilakukan dengan metode LQ (Location Quetion). Dengan analisis ini dapat ditentukan apakah jenis kegiatan perikanan tangkap terkonsentrasi pada suatu wilayah atau tersebar pada beberapa wilayah. Hasil penghitungan LQ data produksi. Dari kondisi komoditas unggulan yang ada di Kawasan Minapolitan Pamboang meliputi ikan tuna, ikan cakalang, ikan tongkol, dan ikan layang.

Tabel 2. Nilai LQ komoditi perikanan tangkap

\begin{tabular}{lcc}
\hline \multicolumn{1}{c}{ Jenis Ikan } & Nilai LQ & Keterangan \\
\hline Ikan Tuna & 1,24 & Unggul \\
Ikan Cakalang & 1,68 & Unggul \\
Ikan Tongkol & 1,14 & Unggul \\
Ikan Layang & 1,39 & Unggul \\
Ikan Karang & 1,07 & Unggul \\
Ikan Campuran & 0,78 & Non Unggul \\
\hline
\end{tabular}

Sumber: hasil analisis tahun 2016

Dari kondisi komoditas unggulan perikanan darat atau perikanan air tawar yang ada di Kawasan Minapolitan Pamboang meliputi udang windu. Adapun kondisi ungul ataupun non unggul merupakan komuditi yang nantinya dapat ditingkatankan pengembangan dan pengelolaan dalam membudidayakan perikanan air tawar/atau tawar.

Tabel 3. Nilai LQ komoditi perikanan darat

\begin{tabular}{lcc}
\hline \multicolumn{1}{c}{ Jenis Ikan } & Nilai LQ & Keterangan \\
\hline Bandeng & 0,94 & Non Unggul \\
Udang Windu & 1,29 & Unggul \\
Ikan Lainnya & 0,83 & Non Unggul \\
\hline
\end{tabular}

Sumber: Hasil analisis, 2016

Salah satu infrastruktur perikanan yang erat kaitannya dengan pengembangan perikanan laut adalah dermaga perikanan atau tempat pelelangan ikan (TPI). Kondisi Pelabuhan perikanan hingga saat ini merupakan infrastruktur yang dibangun pemerintah dengan orientasi pelayanan kepada para pengguna pelabuhan guna memperlancar kegiatan pemasaran produk perikanan dengan harapan kesejahteraan nelayan dapat terwujud. Namun pada faktanya, kompleksitas pemasaran produk ikan yang dihasilkan dari upaya penangkapan sumberdaya ikan di beberapa pelabuhan membuat nilai jual yang diperoleh 
Fatmawaty D, Ikawati dan Erwin Amri, Strategi Pengembangan Kawasan Minapolitan di Kecamatan Pamboang Kabupaten Majene dalam Konsep Pengembangan Wilayah

produsen (nelayan) dan konsumen akhir sangat jauh berbeda. Selain itu, produk yang dihasilkan belum semua memenuhi standar mutu internasional. Agar hasil pemanfaatan sumberdaya ikan oleh nelayan menjadi optimal, maka pelabuhan perikanan harus dapat dikembangkan fungsinya dari pusat pelayanan menjadi pusat pemasaran. Dalam upaya menjadikan pelabuhan sebagai marketing centre maka peran Pelabuhan Perikanan sebagai mata rantai dalam proses transportasi mulai dari tempat asal barang sampai ke tujuan menjadi sangat strategis untuk dikembangkan. Alur produk perikanan mulai dari dermaga pelabuhan hingga dididistribusikan ke tangan konsumen memiliki kesamaan dengan prinsip mata rantai pasokan atau supply chain. Mengingat sifat produk perikanan yang high perishable (mudah rusak) maka dibutuhkan manajemen rantai pasokan yang efektif dan efisien. Salah satu kerangka analisis yang sangat populer digunakan akhir-akhir ini dalam peningkatan nilai tambah dan daya saing dalam industri adalah analisis supply chain (rantai pasokan). Dalam konsep supply chain, pelabuhan dipandang sebagai salah satu bagian dalam satu kesatuan sistem supply chain, yang terdiri dari nelayan, pedagang lokal, industri pengolah, eksportir hingga konsumen akhir.

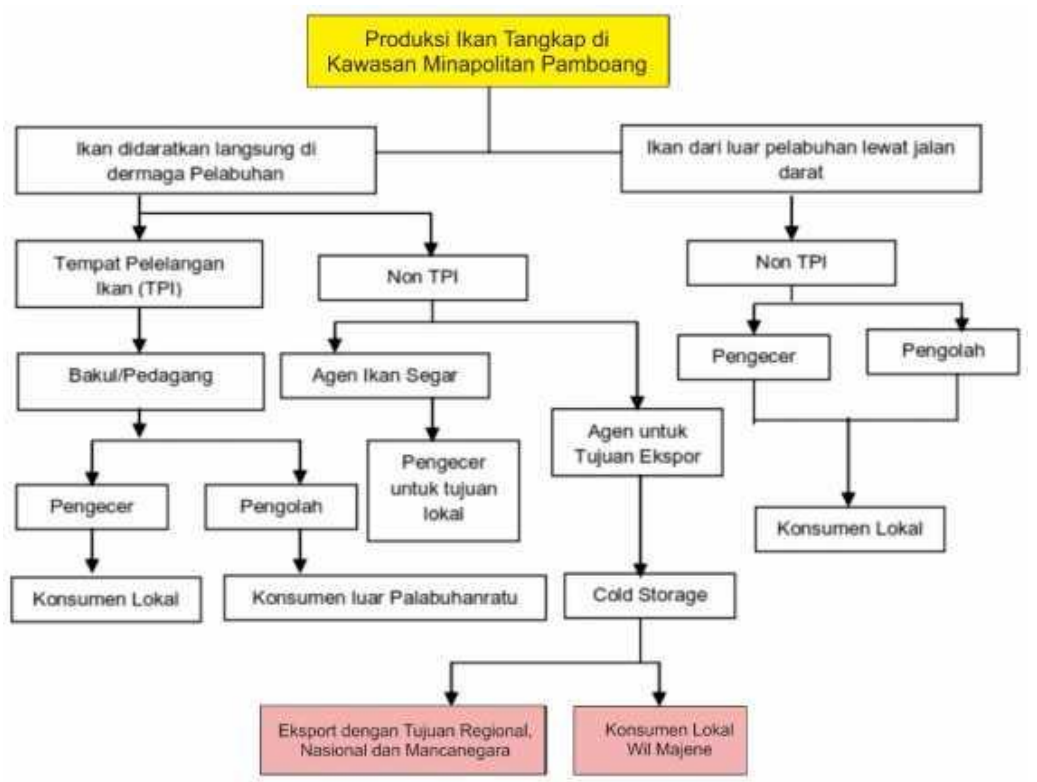

Gambar 1. Pola distribusi hasil perikanan tangkap di kawasan minapolitan

Value chain merujuk kepada fakta jika produk mula-mula akan bertambah nilainya dengan adanya kombinasi dari sumber daya lain seperti alat, tenaga manusia, pengetahuan dan keahlian, bahan baku atau produk awal (ILO, 2009). Value Chain Analysis (VCA) merupakan salah satu konsep pendekatan bagaimana menambah aktivitas dan memperbesar nilai produk secara maksimal dalam tatanan rantai pasok (Stringer, 2009). Berikut proses inti pada value chain perikanan budidaya air tawar di kawasan perencanaan.

Input $\rightarrow$ Produksi $\rightarrow$ Pengumpulan $\rightarrow$ Pengolahan $\rightarrow$ Perdagangan $\rightarrow$ Konsumsi

Gambar 2. Proses inti pada value chain perikanan darat/tawar 
Fatmawaty D, Ikawati dan Erwin Amri, Strategi Pengembangan Kawasan Minapolitan di Kecamatan Pamboang Kabupaten Majene dalam Konsep Pengembangan Wilayah

Dalam mekanisme diatas bahwa proses inti dalam Value chain budidaya air tawar meliputi input samapai pada rantai pasok ke pihak konsumsi masyarakat baik lokal maupun konsumen ekspor.

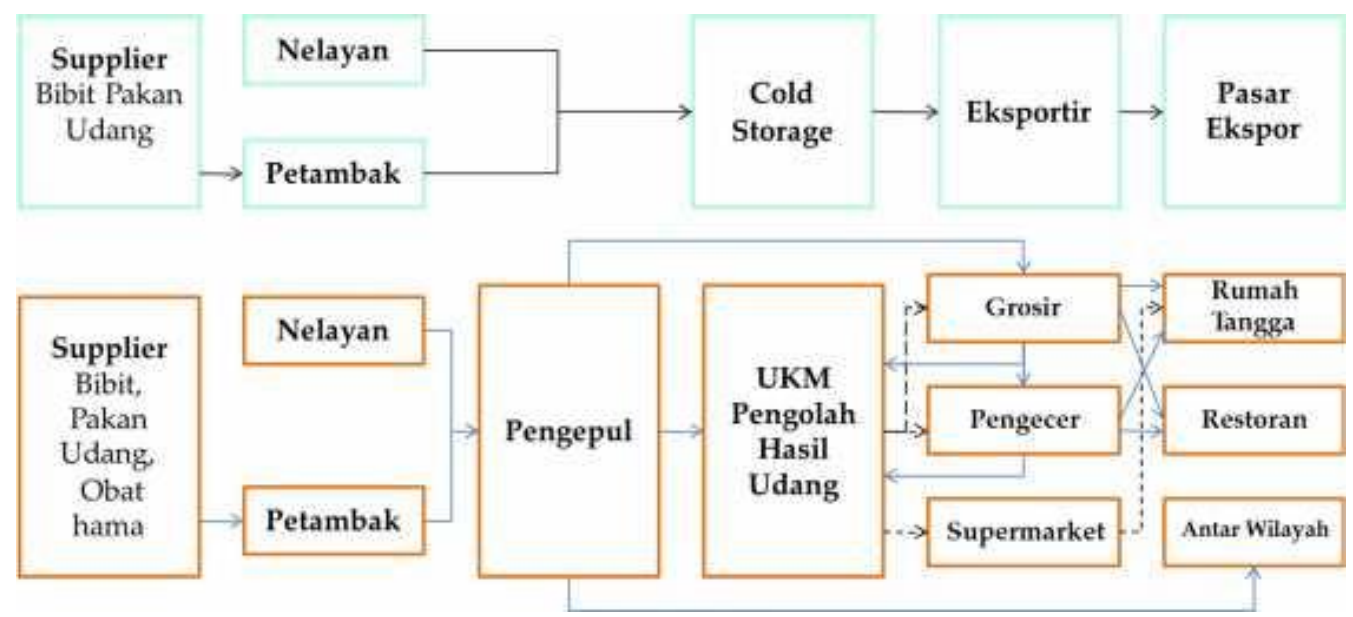

Gambar 3. Value Chain stakeholder perikanan budidaya air tawar

\section{Strategi Pengembangan Kawasan Minapolitan}

Perumusan program pengembangan kawasan minapolitan diperlukan agar tujuan dapat dicapai sesuai dengan rencana yang telah disepakati. Programprogram yang akan dikembangkan harus mengacu kepada visi dan misi pengembangan minapolitan yang sesuai dengan karakteristik wilayah. Untuk mendukung penyusunan program-program yang akan dikembangkan sebaiknya melibatkan semua stakeholder. Penyusunan program sebaiknya dibedakan berdasarkan waktu pencapaian: program jangka pendek, jangka menengah dan jangka panjang. Tujuan dan target penyusunan program sebaiknya dapat terukur, sehingga dapat dilakukan proses pengawasan dan evaluasi.

\section{a. Pengembangan Sentra Produksi Komoditi Unggulan Berbasis Teknologi}

Program pengembangan sentra produksi komoditas unggulan berbasis teknologi bertujuan untuk meningkatkan produksi komoditas-komoditas perikanan yang memiliki daya saing pasar tinggi. Upaya itu dapat dilakukan melalui peningkatan penerapan teknologi tepat guna, sehingga produkstivitas meningkat dan biaya produksi relatif rendah. Dalam proses produksi juga mengacu pada Standar Nasional Indonesia (SNI) sehingga produk yang dihasilkan lebih berkualitas.

Untuk mecapai tujuan di atas, perlu disusun program-program yang menitik beratkan pada peningkatan kualitas sumberdaya manusia dalam keterkaitannya pengelolaan usahanya dan peningkatan kualitas sumberdaya perairan. Program-program ini diharapkan dapat mempercepat tercapainya maksud pembentukan kawasan minapolitan ini, yaitu pengembangan wilayah yang dapat memberikan keuntungan yang besar dan berkesinambungan kepada masyarakat yang ada di dalamnya. Adapun program-program yang akan dilaksanakan, meliputi : 
Fatmawaty D, Ikawati dan Erwin Amri, Strategi Pengembangan Kawasan Minapolitan di Kecamatan Pamboang Kabupaten Majene dalam Konsep Pengembangan Wilayah

1. Program peningkatan kapasitas sumberdaya manusia; peningkatan kemampuan pelaku utama dan petugas teknis perikanan serta penyuluh perikanan untuk memilih teknologi yang tepat guna, peningkatan kemampuan pelaku utama dan petugas teknis perikanan serta petugas teknis perikanan serta penyuluh perikanan dalam mengelola usaha secara komersial.

2. Program pengembangan komoditas unggulan; penggandaan induk ikan unggul, penelitian partisipatif penggunaan induk ikan unggul, pnelitian partisipatif penggunaan teknologi tepat guna dan pendayagunaan sarana produksi.

3. Program peningkatan kualitas sumberdaya lahan; penyusunan peta pewilaylahan komoditas unggulan tingkat detail pada kawasan minapolitan, identifikasi teknik konservasi lahan tepat guna dalam mendukung budidaya perikanan komoditas unggulan potensial pada kawasan minapolitan dan konservasi daerah hulu dan sumber-sumber air lain (danau dan situ).

\section{b. Pengembangan Jaringan Pemasaran Berbasis Teknologi Informasi}

1. Program pengembangan pusat informasi pasar pembuatan pasar ikan yang representatif ; peningkatan jaringan arus informasi dari sentra produksi ke pusat informasi pasar dan penyajian informasi pasar untuk dapat diakses oleh masyarakat luas, peningkatan jaringan kerjasama, informasi dan komunikasi antar pelaku usaha perikanan, dan peningkatan promosi dan kontak-kontak pemasaran, mulai dari tingkat lokal, regional, hingga nasional.

2. Program pengembangan sumberdaya manusia; pelatihan bagi petugas teknis perikanan dan pelaku usaha tentang operasional pemanfaatan teknologi informasi, penyediaan tenaga pengelola pusat informasi pasar yang memiliki kemampuan mengoperasionalkan software sistem informasi pasar dan magang atau kunjungan ke pusat budidaya ikan, pusat pengolahan ikan yang lebih maju.

\section{c. Program Pengembangan Wisatamina}

Pengembangan kawasan perkolaman dan BBI Kabupaten Mejene sebagai lokasi wisatamina; penataan kawasan perkolaman, pengembangan sarana wisatamina, pengembangan koleksi seluruh jenis ikan air tawar, pengembangan promosi perikanan dan pemenuhan kebutuhan sarana dan prasarananya

\section{d. Program Pengembangan Produk Olahan Perikanan}

Dalam rangka membagun sistem bisnis perikanan yang dapat memberikan dampak terhadap kemajuan dan pengembangan wilayah kawasan, produkproduk olahan yang berbasis lokal perlu dikembangkan melalui upaya :

1. Program pengembangan industri rumah tangga, terdiri atas identifikasi pasar dan industri rumah tangga potensial, deminasi paket teknologi pengolahan pasca panen untuk menunjang berdirinya industri rumah tangga yang handal, inkubasi pelaku industri rumah tangga, penyaluran dan pengembangan kredit modal usaha dan dana talangan dan Pengembangan promosi produk olahan. 
Fatmawaty D, Ikawati dan Erwin Amri, Strategi Pengembangan Kawasan Minapolitan di Kecamatan Pamboang Kabupaten Majene dalam Konsep Pengembangan Wilayah

2. Program pengembangan industri berbasis sumber daya lokal; program pengembangan dan peningkatan pemanfaatan dan penerapan iptek untuk peningkatan manajemen pasca panen, program peningkatan industri pengolahan hasil perikanan di sentra-sentra produksi di setiap zona kawasan minapolitan dan program pengembangan model-model pengelolaan industri perikanan yang maju, unggul dan terpadu mulai dari tingkat yang sederhana hingga yang lebih canggih yang dapat menjadi percontohan pengembangan industri perikanan di seluruh kawasan minapolitan.

3. Program pengembangan produk olahan ikan dengan mengunakan lele sebagai bahan substitusi.

\section{KESIMPULAN}

Berkembangnya kawasan minapolitan sangat ditentukan oleh pengembangan komoditas unggulan di setiap kawasan minapolitan. Penetapan komoditas unggulan sangat bermanfaat dalam menentukan prioritas pengembangan di suatu wilayah yang harus disusun secara terstruktur dalam sistem perencanaan yang jelas. Agar pengembangan ini tepat sasaran maka perlu arahan strategi dalam pengembangan komoditas unggulan diantaranya meningkatkan koordinasi lintas sektor, peningkatan sosialisasi dan promosi, peningkatan SDM dan kelembagaan, teknologi tepat guna serta terbangunnya fasilitas fisik minapolitan.

\section{DAFTAR PUSTAKA}

Departemen Kelautan dan Perikanan, 2009. Kelautan dan Perikanan dalam Angka 2009. Jakarta: Departemen Kelautan dan Perikanan.

International Labour Organization, 2009. Global Employment Trends. France: International Labour Office.

Naya, D.A.B., Wijayanto, D \& Sardiyatmo, 2017. Analisis Komoditas Unggulan Perikanan Tangkap di Provinsi Jawa Tengah. Journal of Fisheries Resources Utilization Management and Technology, 6 (3), 37-46.

Stringer, R. 2009. Value Chain Analysis. Workshop Value Chain Analysis. Balai Pengkajian Teknologi Pertanian Nusa Tenggara Barat. 21-33.

Susanto, W, 2014. Kajian Komoditas Unggulan, ANdalan dan Potensial di Kabupaten Grobogan. Journal of Rural and Development, V (1), 63-80. 